Kumawula, Vol. 3, No.3, Desember 2020, Hal 424 - 428 DOI: https://doi.org/10.24198/kumawula.v3i3.27534

ISSN 2620-844X (online)

Tersedia online di http://jurnal.unpad.ac.id/kumawula/index

\title{
WORKSHOP PENERAPAN METODE FIFO PADA GUDANG PERSEDIAAN BARANG DI TOKO KEMANGGISAN
}

\author{
Rimsa Rusmiland ${ }^{1}$, Ridwan Usman ${ }^{2 *}$, Muhammad Fidiandri Putra ${ }^{3}$ \\ ${ }^{1}$ Program Studi Teknik Industri, Fakultas Teknik dan Ilmu Komputer, Universitas Indraprasta PGRI. \\ Jakarta \\ ${ }^{2}$ Program Studi Teknik Industri, Fakultas Teknik dan Ilmu Komputer, Universitas Indraprasta PGRI. \\ Jakarta \\ ${ }^{3}$ Program Studi Teknik Industri, Fakultas Teknik dan Ilmu Komputer, Universitas Indraprasta PGRI. \\ Jakarta
}

*Korespondensi : Rrfj60@gmail.com

\begin{abstract}
ABSTRAK
Persediaan merupakan salah satu perkiraan yang terpenting dalam sebuah perusahaan. Bagi perusahaan, persediaan merupakan asset yang cukup besar nilainya. Konsep penyimpanan diperlukan untuk pemenuhan keberlangsungan usaha. Toko Kemanggisan merupakan unit usaha mini market, toko serba ada menyediakan kebutuhan bahan pokok, peralatan kantor serta perabotan rumah tangga, terutama untuk memenuhi kebutuhkan warga sekitar. Workshop untuk karyawan gudang dalam penerapan metode FIFO (First In First Out) memberikan pengetahuan dan kemampuan tatakelola gudang yang benar, gudang penyimpanan yang bersebelahan dengan Toko Kemanggisan, saat ini sistem penyimpanan barang di Toko Kemanggisan belum menerapkan konsep penyimpanan, salah satunya metode FIFO. Kegiatan pengabdian masyarakat di Toko Kemanggisan, diawali wawancara untuk penentuan kebutuhan mitra, peserta workshop adalah bagian persediaan yaitu staff administrasi dari supplier, staff gudang dan manager operasional, workshop pemahaman, materi penerapan praktik penyimpanan barang dan metode FIFO. Workshop ini menambah ilmu, pengetahuan cara menyimpan barang yang efektif, kemudahan akses pengambilan barang lebih yang cepat dan penyimpanannya lebih teratur.
\end{abstract}

Kata Knnci : Metode penyimpanan produk

\section{WORKSHOP OF THE APPLICATION OF FIFO METHOD IN THE PREPARATION WAREHOUSE AT THE KEMANGGISAN STORE}

\begin{abstract}
Inventory is one of the most important aspects of a company. For companies, inventory is a fairly large asset. The concept of storage is needed to facilitate the continuity of a business. Kemanggisan Shop is a mini market business unit, a convenience store providing basic necessities, office equipment and household furniture, especially to meet the needs of the local residents. The workshop for warehouse employees in applying the FIFO (First In First Out) method provides knowledge and proper warehouse management capabilities, a storage warehouse adjacent to the Kemanggisan Store, currently the goods storage system in the Kemanggisan Store has not applied the concept of storage, one of them is the FIFO method. Community service activities at the Kemanggisan Store, begins with interviews to determine the needs of partners, workshop participants are part of the inventory, which includes administrative staff from suppliers, warehouse staff and operational managers, understanding workshops, material implementation of goods storage practices and FIFO methods. This workshop adds knowledge, including knowledge on how to store goods effectively, easy access faster collection of goods and a more organized storage.
\end{abstract}

Keywords : Product storage method 


\section{PENDAHULUAN}

Toko Kemanggisan merupakan salah satu unit bisnis dari PT. Surya Alam yang bergerak dalam bisnis sebuah mini market yang terletak di Jalan Kemanggisan Ilir Raya No.15 Jakarta Barat. Mini market ini persis sekali terletak dipinggir jalan, jadi untuk mencari mini market kemanggisan ini tidak susah karena lokasinya yang stategis, warga sekitar kemanggisan menyebutnya dengan nama TOKEM (Toko Kemanggisan).

Area mini market tidak terlalu kecil, tetapi cukup banyak menyediakan jenis dan aneka barang yang dibutuhkan warga sekitar. Sudah menjadi kegiatan rutin setiap hari, Toko Kemanggisan menerima barang dari perusahaan/distributor untuk disimpan di gudang yang lokasinya bersebelahan, untuk selanjutnya display sesuai rak yang ada. Petugas gudang di Toko Kemanggisan tentunya belum memahami tentang prinsip FIFO (First In First Out) ini. Pada kenyataannya masih banyak juga barang yang ditempatkan belum terdata maksimal, di gudang belum menerapkan prinsip FIFO (First In First Out) (Sulastri et al., 2020).

Diperlukan konsistensi dalam menerapkan sebuah prinsip yang mendatangkan banyak manfaat, tidak hanya bagi perusahaan tetapi juga bagi pelanggan karena mendapat barang dalam kondisi baik. Penetapan area tanggung jawab diperlukan untuk dapat melakukan pengukuran kemajuan perbaikan dan komitmen karyawan gudang dalam menerapkan prinsip ini. Berdasarkan uraian diatas, maka dapat dirumuskan permasalahan sebagai berikut : masih kurangnya penerapan Metode FIFO (First in First Out) untuk memastikan siklus barang yang di display adalah barang yang pertama kali disimpan di gudang.

Pelaksanaan kegiatan pengabdian kepada masyarakat ini kemitraan dengan toko kemanggisan dan supplier yaitu terdiri dari staff administrasi dari supplier, staff gudang dan manager operasional (Darwis et al., 2020).

\section{METODE}

Tahap awal pengajuan kemitraan tempat abdimas. Setelah disetujui tim melakukan survei pendahuluan dan wawancara terhadap manager operasional untuk mengetahui target kegiataan, kondisi peserta didik yang akan mendapatkan materi dan menyusun rancangan kegiatan yang akan dilakukan. Pelaksanaan kegiatan pengabdian masyarakat di Toko Kemanggisan lokasi mini market ini persis sekali terletak di jalan kemanggisan Ilir Raya No. 15 Jakarta Barat. Tahap pelaksanaan kegiatan dibagi 4 sesi lihat tabel 1 yaitu :

Tabel 1 Tahapan Pelaksanaan

\begin{tabular}{|c|l|l|l|}
\hline No & \multicolumn{1}{|c|}{ Kegiatan } & \multicolumn{1}{|c|}{ Tujuan Kegiatan } & \multicolumn{1}{c|}{ Uraian Kegiatan } \\
\hline 1. & Persiapan awal & $\begin{array}{l}\text { Terjalin kerjasama dan } \\
\text { pemilihan materi }\end{array}$ & $\begin{array}{l}\text { Pengajuan surat tugas ke LPPM } \\
\text { Universitas dan pemilihan materi } \\
\text { pengabdian kepada masyarakat. }\end{array}$ \\
\hline 2. & Pelaksanaan kegiatan & Keikutsertaan peserta & $\begin{array}{l}\text { Team mempresentasikan materi } \\
\text { kepada seluruh peserta }\end{array}$ \\
\hline 3. & Evaluasi materi & $\begin{array}{l}\text { Memahami materi } \\
\text { yang disampaikan }\end{array}$ & Sesi tanya jawab dan diskusi \\
\hline
\end{tabular}




\begin{tabular}{|l|l|l|l|}
\hline 4. & Review pencapaian & Penerapan materi & Survei kelokasi gudang dan toko \\
\hline
\end{tabular}

Berdasarkan uraian diatas, maka diperlukannya kegiatan pengabdian kepada masyarakat, dapat dirumuskan permasalahan, sehingga bagaimana pentingnya dilakukan penataan penyimpanan barang dengan Metode FIFO (First in First Out) untuk memastikan barang yang di display adalah barang yang pertama kali disimpan di gudang.

\section{HASIL DAN PEMBAHASAN}

Kegiatan pengabdian masyarakat dengan kemitraan Toko Kemanggisan memberikan pemahaman, pengalaman praktek penyimpanan barang dengan Metode FIFO (First in First Out), dalam penerapannya diharapkan memberikan kemudahan penempatan dan pemeriksaan barang sehingga pekerjaan menjadi efektif dan efisien. Dalam tahap pelaksanaan pada tabel 1 sebagai berikut ini :

1. Tahap awal sudah pengajuan surat tugas kemitran abdimas yang diterbitkan LPPM Universitas. Survei lokasi ketoko kemanggisan bertemu langsung manager operasional wawancara, penentuan waktu, kebutuhan dan kendala yang dihadapi mitra, ini sebagai dasar pemilihan materi, sehingga pengumpulan informasi awal bertujuan untuk mewujudkan kesuksesan kegiatan pengabdian masyarakat.

2. Tahap pelaksanaan kegiatan wokrshop dan penyuluhan dilakukan team dengan memaparkan teori pemahaman dan pengetahuan penerapan metode FIFO (First in first out) penjelasan materi kepada peserta meliputi Metode persediaan dilakukan dengan empat cara yaitu.

\section{A. Metode identifikasi khusus}

Metode identifikasi khusus mensyaratkan bahwa setiap barang yang disimpan harus ditandai secara khusus sehingga biaya per unit nya dapat diidentifikasi setiap waktu.

B. Metode Rata-rata

Dalam metode ini barang-barang yang dipakai atau dijual akan dibebani harga pokok rata-rata. Perhitungan harga pokok rata-rata dilakukan dengan cara membagi jumlah harga perolehan dengan kuantitasnya.

C. Metode FIFO (First in first out) Metode FIFO (First In First Out) mengasumsikan bahwa barangbarang yang digunakan sesuai dengan urutan pembeliannya. Metode ini mengasumsikan bahwa barang pertama dibeli adalah barang yang pertama digunakan atau dijual (Skousen, 2004).

D. Metode LIFO (Last In First Out) Metode LIFO (First In First Out) menandingkan biaya dari barangbarang yang paling akhir dibeli terhadap pendapatan. Persediaan akhir akan ditentukan dengan menggunakan unit total sebagai dasar perhitungan dengan mengabaikan tanggal-tanggal pembelian yang terlibat. (Skousen, 2004).

Pendukung peralatan yang digunakan dalam workshop adalah laptop, untuk presentasi LCD Projector untuk presentasi, materi difotocopy untuk peserta, yaitu terdiri dari staff administrasi dari supplier, staff gudang dan manager operasional. Gambar 1 Pelaksanaan workshop pengabdian kepada masyarakat di toko kemanggisan. 


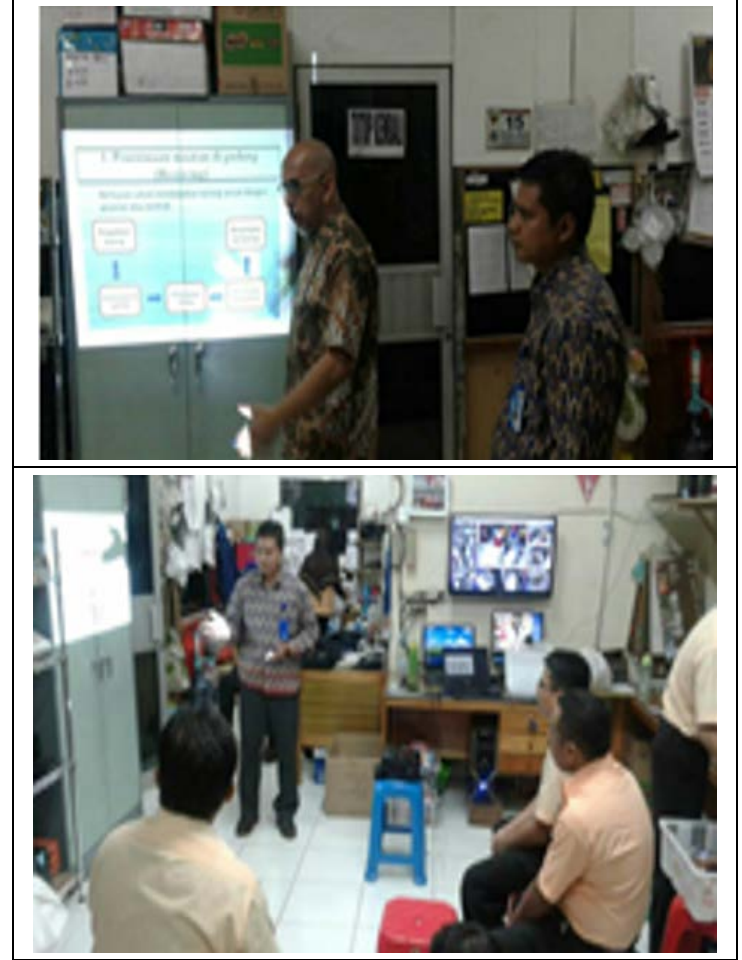

Gambar 1. Pelaksanaan workshop pengabdian kepada masyarakat

3. Tahap berikutnya review materi yang telah disampaikan melalui sesi diskusi, tanya jawab dan evaluasi terkait pemaparan materi dengan melihat peran serta peserta dalam kegiatan ini bersemangat, antusias dan diskusi yang berjalan lancar, sehingga peserta pengabdian kepada masyarakat mendapatkan pengetahuan baru.

4. Tahap terakhir yaitu kunjungan melihat lokasi penyimpanan gudang dari mulai penerimaan, penyimpanan lihat Gambar 2 Kunjungan area gudang penyimpanan barang di toko kemanggisan.

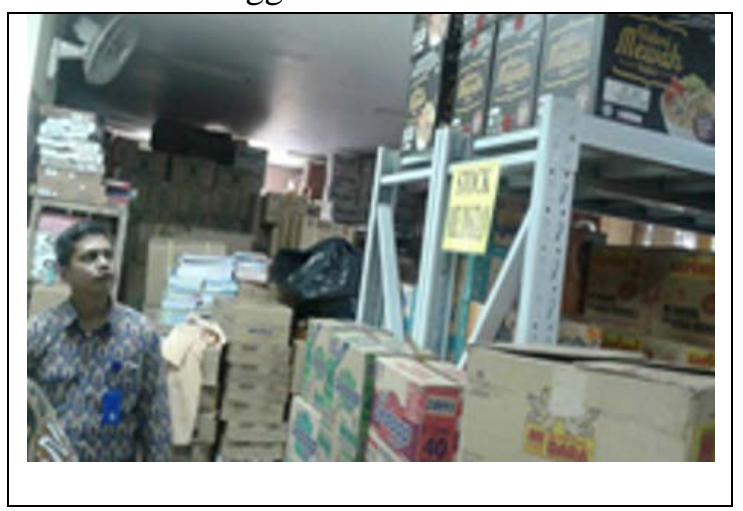

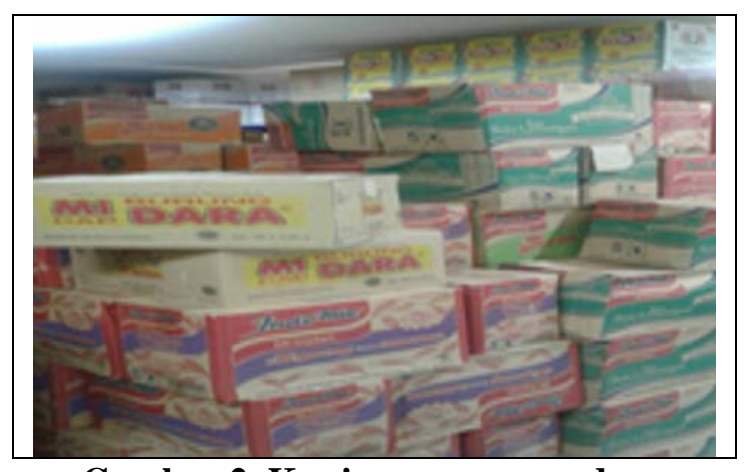

\section{Gambar 2. Kunjungan area gudang} penyimpanan

Selain gudang kunjungan dilanjutkan ke area toko tempat pemasangan display barang yang dijual. Lokasi toko kemanggisan Gambar 3 Kunjungan toko melihat pemasangan display barang-barang yang dijual.

Adapun kegiatan ini bertujuan memberikan teori pemahaman dan pengetahuan tentang cara penyimpanan barang yang efektif dengan metode FIFO (First in first out), Akses barang lebih cepat dan penyimpanan barang lebih teratur. Selama ini belum efektif melakukan penerapan metode FIFO (First in first out) di toko kemanggisan. Informasi teori pemahaman dan pengetahuan menambah pengetahuan kepada peserta abdimas, sehingga proses yang akan dilakukan bagian persedian diharapkan kedepannya akan lebih baik lagi berjalan cepat dan lancar.

\section{SIMPULAN}

Kesimpulan dalam kegiatan workshop pengabdian masyarakat ini ditunjukkan adanya tingkat pemahaman dan pengetahuan materimateri yang berkaitan cara penyimpanan barang yang efektif dengan metode FIFO (First in first out) dan Warehouse Management, sehingga dapat ditarik kesimpulan yaitu :

1. Workshop yang telah diikuti oleh peserta dari pengetahuan baru yang didapat terkait metode FIFO (First in first out) dan Warehouse Management, metode ini bisa langsung diterapkan digudang toko kemanggisan.

2. Pernyesuaian dan perbaikan sistem data,metode penyimpanan bertujuan peningkatkan produktivitas yang berkesinambungan.

Untuk kegitaan selanjutnya mitra pengadian kepada masyarakat berharap ada kegiatan serupa yang mendukung kinerja mereka terutama berkaitan dengan 
penyimpanan barang yaitu manajemen gudang, tata letak penyimpanan dan prosedur kerja pergudangan dan lain-lain

\section{DAFTAR PUSTAKA}

Darwis, R. S., Resnawaty, R., \& Nuriyah, E. (2020). Peningkatan Sensitivitas Kepemimpinan Lokal Dalam Pengelolaan Sungai Citarum Melalui Teknik Participatory Rural Appraisal (Pra) Di Desa Rancamanyar. Kumawula: Jurnal Pengabdian Kepada Masyarakat, 3(1), 48.

https://doi.org/10.24198/kumawula.v3i1. 24820

F Robert Jacobs \& Richard B.Chase, 2011. Operation and Supply Chain Management, 14th. Global Edition, Mc Graw Hill, New York USA

Heizer, Jay and Barry Bender, 2001. Operation Management, 6th edition, PrenticeHall.Inc, New Jersey

Mulyono Sri, 2004. Riset Operasi, Edisi pertama, Penerbit BPFE, Jogyakarta

Stice, Earl K, James D Stice dan Fred Kousen, 2009.

Akuntansi Keuangan Menengah, Edisi 16, Buku 2, Edisi Bahasa Indonesia. Terjemahan oleh Ali Akbar. Jakarta. Salemba Empat

Subagyo, Pangestu. 2000. Riset Operasi, Edisi Pertama. Yogyakarta: BPFE

Sulastri, S., Krisnani, H., \& Hidayat, E. N. (2020). PENCATATAN DAN PENGOLAHAN DATA MIKRO KELUARGA Pembentukan Kampung Keluarga Berencana ( KB ) yang dicanangkan oleh Presiden miskin yang relatif lebih tinggi atau jumlah peserta KB yang relatif lebih rendah dari rata-rata yang diprakarsai oleh masyarakat ,. Kumawula: Jurnal Pengabdian Kepada Masyarakat, 3(2), 174-188. 